\title{
Interpersonal Metadiscourse Markers in Opinion Articles: A Study of Texts Written by Indonesian Writers
}

\author{
Bayu Permana Sukma \\ Faculty of Humanities, Universitas Padjadjaran \\ Jl. Raya Bandung - Sumedang Km. 21, Jatinangor, Sumedang 45363, West Java, Indonesia \\ E-mail: bayu11014@student.unpad.ac.id \\ Eva Tuckyta Sari Sujatna \\ Faculty of Humanities, Universitas Padjadjaran \\ Jl. Raya Bandung - Sumedang Km. 21, Jatinangor, Sumedang 45363, West Java, Indonesia \\ E-mail: evatuckyta@unpad.ac.id
}

Received: 05-10-2013

Accepted: 27-11-2013

Published: 01-03-2014

doi:10.7575/aiac.ijalel.v.3n.2p.16

URL: http://dx.doi.org/10.7575/aiac.ijalel.v.3n.2p.16

\begin{abstract}
Writers can apply interpersonal metadiscourse markers to encode an interaction and build a relationship with their readers. In some particular genres, such as newspaper discourse, they can even be used as means of attaining persuasive goals. Initiated by the idea, the present writer attempts to explore the use of interpersonal metadiscourse markers in Indonesian newspaper opinion articles. This present study aims to investigate interpersonal metadiscourse categories and subcategories applied and most predominantly occuring in the type of newspaper article. For the data, eleven selected articles of an Indonesian newspaper were taken to analyze by using Dafouz's (2008) classification of interpersonal metadiscourse markers. Results reveal that interpersonal metadiscourse categories (hedges, certainty markers, attributors, attitude markers, and commentaries) and subcategories (epistemic verbs, probability adverbs, deontic verbs, attitudinal adverbs, attitudinal adjectives, cognitive verbs, rhetorical questions, inclusive expressions, personalizations, and asides) were used in Indonesian opinion articles. It is also found that attitude markers and two subcategories, which are deontic and epistemic verbs, are most frequently present in the texts.
\end{abstract}

Keywords: Interpersonal metadiscourse markers, newspaper discourse, Indonesian newspaper, opinion articles

\section{Introduction}

Newspaper is one of the most popular written discourses in all over the world. It has already become a very important public media having a wide range of audience for a long time because of its significant role in serving people information related to their world. Even if nearly a decade of massive transition from paper use to paperless or digital era indicated by the occurrence of new media such as internet, especially in Indonesia, it never really loses its loyal readers. People in Indonesia, mostly the middle class, could never lose their interest in newspaper since they consider that the low-cost source of information is easy to carry and able to read for many times, yet still serves more in-depth information than the other media give (Kompas Center for Research and Developing 2012 survey).

As one of public sources of information, newspaper generally offers two kinds of text type, namely editorial and opinion article or column. Both of them have special characteristics. On one hand, they have similarity on serving topics which is "of particular societal importance at the time of publication" (Le, 2004, p. 688). On the other hand, the two kinds of newspaper text type also have some differences. While editorials are normally written by reporters and editorialists and represent the position of the newspaper, opinion articles are usually written by experts and do not reflect official viewpoint of the newspaper. Because of this characteristic, opinion article is regarded as an adequate example of persuasive writing in all countries setting standards for written persuasion (Connor, 1996).

In line with the argument, van Dijk (1988) proposes opinion article as one of subgenres of persuasive text aiming to persuade and convince the readers through the writing. Considering the purpose, it can be concluded then that the success of writing this kind of text will be very much determined by writer's skill in balancing between giving information and persuading the readers. A writer should have not only excellent skill in organizing ideas and arguments in order to shape an attracting content but also outstanding ability to build relationship and emotional ties with the readers. The better a writer interacts with readers, the easier he or she talks to them and attains persuasive goals.

One of linguistic features which can be applied to construct a good rapport with audience in text is interpersonal metadiscourse. This feature is closely related to persuasive writing since it specifically explores interpersonal relationship and interaction between addresser and addressee. Thus, interpersonal metadiscourse markers will be easy to find in persuasive text, especially opinion article. 
Studies of interpersonal metadiscourse in journalistic texts have started to receive attention in some countries. It is proved by some research conducted by researchers such as Abdollahzadeh (2007) examining Persian and English newspaper editorials, Dafouz $(2003$, 2008) exploring the Spanish and the British newspaper, Le (2004) investigating editorialists' authority, and Noorian and Biria (2010) comparing opinion articles written by American and Iranian. However, unfortunately, to the present writers' knowledge, there is no study so far investigating interpersonal metadiscourse in Indonesian newspaper discourse, especially opinion article. Thus, this present study tries to explore this field by proposing two research questions: What interpersonal metadiscourse markers are used in Indonesian newspaper opinion articles? What interpersonal metadiscourse markers most predominantly occur in the newspaper opinion articles?

\section{Theoretical Background}

Every writer interacts with readers in their texts. The interaction may be encoded explicitly or implicitly by some linguistic expressions called metadiscourse. Vande Kopple (1985) defines metadiscourse as:

discourse that people use not to expand referential material but to help their readers connect, organise, interpret, evaluate, and develop attitudes toward the material. (p. 83)

The definition is very much in line with what Crismore et al. (1993) propose. They state that metadiscourse is:

the linguistic material in text that does not add anything to the propositional content but that is intended to help the listener or reader organize, interpret, and evaluate the information given. (p. 41)

Both definitions are derived from the notion that writer (or speaker) communicates in two levels, that is primary level and metadiscourse level (Vande Kopple, 1985; Crismore et al, 1993). Vande Kopple (1985) and Crismore et al. (1993) suggest that in the first level, writer is presenting propositional content, while in the second level he/she is attempting to guide his or her readers (or listeners) to an understanding. Therefore, metadiscourse works in the second level.

The concept of metadiscourse has evolved significantly since it was coined first by Zellig Harris in 1959. Some of metadiscourse analysts, such as Vande Kopple (1985), Crismore et al (1993), and Hyland $(1998,2005)$ propose some categorizations of metadiscourse. They generally classify it into two major categories based on Hallidayan functional approach, namely textual and interpersonal metadiscourse (Hyland, 2005). Each of the categories holds particular function respectively. Textual metadiscourse helps writer create a well-structured text and guide the readers by organizing and making a text cohesive and coherent, while interpersonal metadiscourse focuses on building a relationship between the writer and the readers (Dafouz, 2003). Moreover, it allows writers to express their attitude towards the content of texts and the readers (Hyland, 1999). Because of those functions, Dafouz (2003) argues that both metadiscourse categories can fulfill persuasive aims. Nevertheless, the degree of persuasion they carry is not precisely the same, since interpersonal metadiscourse is considered to hold more persuasive function than the textual one ((Dafouz, 2003).

One of metadiscourse theorists conducting some research in newspaper discourse is Dafouz (2003, 2008). By developing Crismore's et al's. (1993) categorization, she proposes a classification system of interpersonal metadiscourse for persuasive writings, especially journalistic texts (see Table 1).

Table 1. Interpersonal metadiscourse categories (Dafouz, 2008)

\begin{tabular}{|c|c|c|}
\hline Macro-category & Subcategory & Examples \\
\hline \multirow{4}{*}{$\begin{array}{l}\text { Hedges } \\
\text { Express partial commitment to the } \\
\text { truth-value of the text }\end{array}$} & & \\
\hline & Epistemic verbs & May / might / it must be two o'clock \\
\hline & Probability adverbs & Probably / perhaps / maybe \\
\hline & Epistemic expressions & It is likely \\
\hline \multicolumn{2}{|l|}{ Certainty markers } & \\
\hline \multicolumn{2}{|l|}{$\begin{array}{l}\text { Express total commitment to the } \\
\text { truth-value of the text } \\
\text { Attributors }\end{array}$} & Undoubtedly / clearly / certainly \\
\hline \multicolumn{2}{|l|}{ Refer to the source of information } & $\begin{array}{l}\text { ' } x \text { ' claims that.../ As the Prime Minister } \\
\text { remarked }\end{array}$ \\
\hline \multirow{5}{*}{$\begin{array}{l}\text { Attitude markers } \\
\text { Express writers' affective values } \\
\text { towards text and readers }\end{array}$} & & \\
\hline & Deontic verbs & Have to / we must understand / needs to \\
\hline & Attitudinal adverbs & Unfortunately / remarkably / pathetically \\
\hline & Attitudinal adjectives & It is absurd / it is surprising \\
\hline & Cognitive verbs & I feel / I think / I believe \\
\hline \multirow{6}{*}{$\begin{array}{l}\text { Commentaries } \\
\text { Help to establish reader-writer } \\
\text { rapport through the text }\end{array}$} & & \\
\hline & Rhetorical questions & $\begin{array}{l}\text { What is the future of Europe, integration or } \\
\text { disintegration? }\end{array}$ \\
\hline & Direct address to reader & You must understand, dear reader \\
\hline & Inclusive expressions & We all believe / let us summarise \\
\hline & Personalizations & $\begin{array}{l}\text { What the polls are telling me / I do not } \\
\text { want }\end{array}$ \\
\hline & Asides & $\begin{array}{l}\text { Diana (ironically for a Spencer) was not of } \\
\text { the Establishment }\end{array}$ \\
\hline
\end{tabular}


Dafouz (2008) classifies interpersonal metadiscourse into five major categories, that is hedges, certainty markers, attributors, attitude markers, and commentaries. The three of five major categories (hedges, attitude markers, and commentaries) are then divided into some subcategories to mark their specific forms in text.

Each major categories respectively operates particular function. Hedges and certainty markers show writer's degree of commitment to the truth-value of the text. While hedges function to weaken writer's expression, certainty markers help strengthen a statement. Hedges can be realized by epistemic verbs, probability adverbs, and epistemic expressions, while certainty markers are indicated by adverbs of certainty.

Attributors help writer give support to his/her own arguments. Meanwhile, attitude markers specifically indicate writer's affective attitude towards both content of the text and the readers. They can be expressed by deontic verbs, attitudinal adverbs, attitudinal adjectives, and cognitive verbs. Finally, commentaries, indicated by rhetorical questions, direct address to reader, inclusive expressions, personalizations, and asides, focus on building close relationship between the writer and the readers.

In Bahasa Indonesia, interpersonal metadiscourse markers can be realized by hedges such as mungkin, barangkali, bisa saja, bisa jadi, boleh jadi, seharusnya, sebaiknya, semestinya; certainty markers such as tentu, tentu saja, jelas, sepenuhnya; and attitude markers like harus, wajib, mesti (deontic verbs); sayangnya, rupanya, ternyata, sebenarnya (attitudinal adverbs); wajar, tak heran, tak aneh (attitudinal adjectives). Regarding the other categories and subcategories, such as attributors and rhetorical questions, there is no significant difference in form between Bahasa Indonesia and English.

\section{Method}

\subsection{Material}

The data of this study were taken from opinion articles of Kompas, one of the most well-known Indonesian newspapers. The newspaper was chosen as data source since it is widely read by Indonesian people and was granted one of the best top ten newspapers by Indonesian Press Council. In addition, the opinion articles of the newspaper are mostly written by leading figures of the country, such as professionals, politicians, activists and academics.

Eleven article texts (each of them consists of nearly 600 to 800 words) written by Indonesians (as native speakers of Indonesian) during the $7^{\text {th }}$ to the $21^{\text {st }}$ of September 2013 were selected. The texts were selected based on the similarity in topic concerning legal and political issues. The issues are chosen since they are currently attracting most Indonesian people attention and interest, especially the middle class.

\subsection{Procedure}

This present study focuses on the use of interpersonal metadiscourse markers. Thus, after selecting the articles, the present writer identified and categorized the interpersonal metadiscourse markers based on Dafouz's (2008) classification. After that, each categories and subcategories were counted to investigate the frequency of occurrence.

\section{Results and Discussion}

Based on the analysis, the present writer finds interesting results regarding the frequency of occurrence of interpersonal metadiscourse markers in Indonesian opinion articles. The findings reveal that attitude markers are most frequently used in the data. The occurrence of the category is forty three times (39.81\%). They are followed by commentaries (twenty nine times $(26.85 \%)$ ), hedges (twenty times $(18.51 \%)$ ), certainty markers (eleven times $(10.18 \%)$ ), and attributors (five times $(4.62 \%))$.

Regarding the interpersonal metadiscourse subcategories, it is found that attitudinal adverbs which occur twenty one times $(22.82 \%)$ ) in the data get the highest ranking, followed by epistemic verbs and deontic verbs (eighteen times $(19.56 \%)$ ) in shared second place. Further, inclusive expressions (thirteen times $(14.13 \%)$ are in third place, followed by rhetorical questions (nine times $(9.78 \%)$ ), personalizations (five times $(5.43 \%)$ ), and attitudinal adjectives (three times $(3.26 \%)$ ). Probability adverbs and asides are in seventh place since they reach the same total number of occurrence (two times $(2.17 \%))$. The lowest position is occupied by cognitive verbs which only occur once $(1.08 \%)$ in the texts. Meanwhile, there is no epistemic verbs and direct address to reader found in the data.

Those results are illustrated by the following table:

Table 2. Frequency of occurrence of interpersonal metadiscourse categories and subcategories

\begin{tabular}{|l|l|c|}
\hline \multicolumn{1}{|c|}{ Macro-category } & \multicolumn{1}{|c|}{ Subcategory } & Number of markers \\
\hline Hedges & 20 (18.51\%) \\
& Epistemic verb & $18(19.56 \%)$ \\
& Probability adverbs & $2(2.17 \%)$ \\
& Epistemic expressions & - \\
\hline Certainty markers & - & $\mathbf{1 1 ( 1 0 . 1 8 \% )}$ \\
\hline Attributors & - & $\mathbf{5 ( 4 . 6 2 \% )}$ \\
\hline Attitude markers & & $\mathbf{4 3 ( 3 9 . 8 1 \% )}$ \\
& Deontic verbs & $18(19.56 \%)$ \\
& Attitudinal adverbs & $21(22.82 \%)$ \\
& Attitudinal adjectives & $3(3.26 \%)$ \\
& Cognitive verbs & $1(1.08 \%)$ \\
\hline
\end{tabular}




\begin{tabular}{|l|l|c|}
\hline Commentaries & & $\mathbf{2 9}(\mathbf{2 6 . 8 5 \% )}$ \\
& Rhetorical questions & $9(9.78 \%)$ \\
& Direct address to reader & - \\
& Inclusive expressions & $13(14.13 \%)$ \\
& Personalizations & $5(5.43 \%)$ \\
& Asides & $2(2.17 \%)$ \\
\hline
\end{tabular}

The finding revealing that attitude markers are the most frequent category used in the data seems closely related to the topic of the articles, namely legal and political issues. Since while talking about those issues, the writers tend to more clearly express their attitudes towards the content of text and the readers. The high ranking of their two subcategories, attitudinal adverbs and deontic verbs, also indicates that the writers try to show their personal feelings, concern and commitment more, specifically when it comes to the issues of democracy, corruption or political ethic. The use of attitude markers in selected articles is shown by the following examples. Deontic verb is typed in bold in example (1), attitudinal adverb in example (2), attitudinal adjective in example (3), and cognitive verb in example (4).

(1) Article 1 "Demokrasi atau Borjuasi” ('Democracy or Bourgeoisie')

Demokrasi harus dikembalikan kepada substansinya, patriotisme.

'Democracy must be brought back to its substance that is patriotism.'

(2) Article 8 “Demokratisasi Negara Hukum” ('Legal State Democratization')

Pergeseran kekuasaan itu sesungguhnya memberikan sinyal positif.

'The power shifting frankly gives positive signal.'

(3) Article 10 "Lupakan Jokowi” ('Forget about Jokowi')

Tak heran, Jokowi ibarat setetes air di bejana kosong republik ini.

'It is unsurprising that people consider Jokowi as if he were an oasis of this republic.'

(4) Article 11 "Antara Jokowi dan "Surveyor"” ("Between Jokowi and the "Surveyors"”)

Saya sadar, para "pengikut”-nya yang setia akan tidak suka terhadap artikel ini.

'I know that his loyal "followers" will be uninterested in this article.'

Meanwhile, commentaries are the second most frequent category based on the findings. It indicates the writers' strong commitment to create a writer-reader relationship through the text. By employing the subcategory of interpersonal metadiscourse marker, the writers attempt to touch their audience's emotion.

Of four commentaries subcategories, inclusive expressions are found most frequently in the data. This finding reveals that the writers are more concerned with establishing solidarity by taking the same position as the audience. In regard to personalizations, the finding seems to show similarity to Iranian opinion article writers in Noorian and Biria's (2010) study, in which they employ this subcategory less. The similarity in both groups of writers may also be closely related to their common culture. Actually, employing less personalizations could minimize or withhold the sense of subjectivity, but as the consequence, it also creates distance and decreases the degree of interaction in the text (Noorian and Biria, 2010).

The example of rhetorical questions, inclusive expressions, personalizations, and asides used in the data is shown below:

(5) Article 2 "Polisi Melawan Korupsi” ('The Police Against Corruption')

Bagaimana membuat mekanisme ini efektif? Tentu butuh komitmen penuh pemimpin Polri.

'How can we make this mechanism effective? Of course it needs full commitment from the Indonesian National Police chief officers.'

(6) Article 10 "Lupakan Jokowi” ('Forget about Jokowi')

Kita semua tahu bahwa SBY yang melahirkan Partai Demokrat, bukan sebaliknya.

'We all know that it is SBY (Susilo Bambang Yudhoyono) who promoted the Democrat Party, not otherwise.'

(7) Article 11 "Antara Jokowi dan "Surveyor"” ('Between Jokowi and the "Surveyors"')

Saya sadar, para "pengikut”-nya yang setia akan tidak suka terhadap artikel ini.

'I know that his loyal "followers" will be uninterested in this article.'

(8) Article 7 “Demokrasi dan Politik Islam” ('Democracy and Political Islam')

Mereka kemudian mengembangkan kepentingan untuk berjuang secara demokratis (walau bukan tanpa kritik) guna melindungi diri dari kekuatan otoriterisme lama.

'They then develop an interest to struggle democratically (even sometimes followed by criticisms) in order to save themselves from the power of the old authoritarianism.'

The third most frequent category found in the data is hedges. This category function to help writers withhold full commitment and make the text seem to be more polite and friendly (Camiciottoli, 2003). Actually, hedges are considered as important items in persuasive texts since they are argued to give balance between expressing strong commitment to writer's ideas and respecting audience's arguments (Dafouz, 2013). Nevertheless, the results disclose 
that this category is not frequently used (with the absence of epistemic expressions) in the selected texts. It is quite surprising to know that this is contrary to some studies (Dafouz, 2003, 2008; Noorian and Biria, 2010) indicating that hedges are most frequently used by some groups of writers, such as the Americans, British, Spanish, and Iranians.

Example (9) and (10) below represent the use of hedges (epistemic verb is shown in (9) while probability adverb is shown in (10)).

(9) Article 4 "Kompetisi Asimetris" ('Asymmetrical Competition')

Ia juga membentuk Relawan ReDI (Relawan Demi Indonesia) yang mungkin berasal dari kata dalam bahasa Inggris, ready, atau siap jadi presiden RI.

'He also founded Volunteer ReDI (Relawan Demi Indonesia -Volunteers for Indonesia-) which may be derived from the English word, ready, or ready to become the president of RI (the Republic of Indonesia).'

(10) Article 5 "Calon Presiden Pilihan Survei” ('The Surveys' Candidate of President')

Barangkali memang demikian adanya: politisi dituntut untuk profesional dalam merespons banyak hal, tetapi tetap dibarengi dengan kecanggihan merawat basis dukungan.

'Maybe it is a fact: politicians must be not only professional in responding various things, but also excellent in maintaining basis of support.'

The next category standing in fourth place after hedges is certainty markers. As the opposite of hedges, this category is generally employed to emphasize certainty and exposing writer's expertise instead of weakening expressions or softening statements. According to Dafouz (2003), certainty markers hold impotant role in the construction of ethos in persuasive writings. Ethos is simply defined as "personal appeal of one's character" (Hyland, 2005, p. 64). Thus, by employing this category in their analysis (as shown in example (11)), the writers attempt to show the audience their credibility and expertise in a field, in this case law and politics.

(11) Article 4 "Kompetisi Asimetris" ('Asymmetrical Competition')

Tentu tak semua orang yang aktif dalam jaringan itu mau dikaitkan dengan aktivitas politik inspirator pendidikan Indonesia ini.

'Of course not all people in the networks are willing to be associated with the political activity of the Indonesian education inspirer.'

Finally, attributors are the least frequent category employed in the data. This finding again coincides with Noorian and Biria's (2010) study concerning the use of attributors by Iranian opinion article writers. It could also indicate that Indonesian writers tend to be more dependent on their own ideas and arguments in attaining persuasive goals through a text.

(12) Article 9 "Republik Kartel" ('The Republic of Cartel')

Berbagai upaya mereformasi struktur birokrasi maupun merestrukturisasi organisasi publik hanya menyentuh aspek struktur semata-mata dan gagal menginternalkannya menjadi rujukan etis perilaku fungsional para elite. Dalam pandangan Foucault, hal itu dikatakan sebagai sebuah kegilaan yang menyebabkan totalitas jiwa sebagian elite yang berperilaku koruptif terfragmentasi sehingga memisahkan manusia dari realitas dirinya.

'Every effort to reform the structure of bureaucracy and restructure public organization merely impacts on structural aspects that fails to be internalized as ethic reference for the elites' functional behavior. Foucault argues that this fact is a kind of insanity fragmenting the totality of some corrupt ellites' soul and separating themselves from their reality.'

In regard to the function of this category in persuasive texts, the finding also seems to confirm what Noorian and Biria (2010) propose. It is found that attributors are used by the writers to support and justify their arguments on an issue, as example (12) shows.

\section{Conclusion}

The results of this present study suggest that interpersonal metadiscourse markers realized by some categories and subcategories are employed in Indonesian newspaper opinion articles. The categories which can be found are hedges certainty markers, attributors, attitude markers, and commentaries. Based on the analysis, it is also found that attitude markers $(39.81 \%)$ are the most frequent category used in the data, followed by commentaries $(26.85 \%)$, hedges (18.51\%), certainty markers $(10.18 \%)$, and attributors $(4.62 \%)$.

Regarding the subcategories, the findings reveal that attitudinal adverbs (22.82\%) are most frequently present in the selected articles, followed by other types, namely epistemic and deontic verbs $(19.56 \%)$ reaching the same number of occurrence, inclusive expressions (14.13\%), rhetorical questions $(9.78 \%)$, personalizations $(5.43 \%)$, and attitudinal adjectives (3.26\%). Finally, the two lowest rankings are occupied by asides $(2.17 \%)$, probability adverbs $(2.17 \%)$ and cognitive verbs $(1.08 \%)$ while the rest of two subcategories, that is epistemic expressions and direct address to reader are absent in the data.

Those findings might be closely related to the writers' cultural preferences, as Dafouz (2003), Hyland (2004), and Noorian and Biria (2010) suggest that they potentially affect the use of metadiscourse markers in a text. As the consequence, one group of writers with different cultures may differ from others in choosing those markers. In addition, the results of the present study might also be influenced by the selected topic of the articles as suggested by Dafouz 
(2003). For both reasons, therefore, the present writers suggest that future studies explore the use of interpersonal metadiscourse markers by selecting other topics of writing or by conducting contrastive studies to compare Indonesian writers' markers choice with other different cultural groups of writers. The concerned researchers may also expand corpus size, in this case the number of selected articles to get clearer insight in this area.

\section{Acknowledgement}

The present writers would like to thank Heriyanto and all colleagues for their constructive comments and suggestions.

\section{References}

Abdi, R. (2002). Interpersonal metadiscourse: An indicator of intercation and identity. Discourse Studies, 4(2), 139-145. Abdollahzadeh, E. (2007). Writer's presence in Persian and English newspaper editorials. Paper presented at the International Conference on Systemic Functional Linguistics in Odense, Denmark.

Camiciotolli, B. C. (2003). Metadiscourse and ESP reading comprehension: An exploratory study. Reading in a Foreign Language, 15(1), 28-44.

Connor, U. (1996). Contrastive rhetoric: Cross-cultural aspects of second language writing. New York: Cambridge University Press.

Crismore, A., Markkanen, R., \& Steffensen, M. S. (1993). Metadiscourse in persuasive writing: A study of texts written by American and Finish university students. Written Communication, 10(1), 39-71.

Dafouz, E. (2003). Metadiscourse revisited: A contrastive study of persuasive writing in professional discourse. Estudios Ingleses de la Universidad Complutense, 11, 29-52.

Dafouz, E. (2008). The pragmatic role of textual and interpersonal metadiscourse markers in the construction and attainment of persuasion: A cross-linguistic study of newspaper discourse. Journal of Pragmatics, 40, 95-113. doi: 10.1016/j.pragma.2007.10.003

Hyland, K. (1998). Persuasion and context: The pragmatics of academic discourse. Journal of Pragmatics, 30, 437-455.

Hyland, K. (1999). Talking to students: Metadiscourse in introductory coursebooks. English for Specific Purposes, $18(1), 3-26$.

Hyland, K. (2004). Disciplinary interactions: Metadiscourse in L2 postgraduate writing. Journal of Second Language Writing, 13, 133-151.

Hyland, K. (2005). Metadiscourse: Exploring interaction in writing. Oxford: Continuum.

Le, E. (2004). Active participation within written argumentation: Metadiscourse and editorialist"s authority. Journal of Pragmatics, 36, 687-714.

Noorian, M. \& Biria, R. (2010). Interpersonal metadiscourse in persuasive journalism: a study texts by American and Iranian EFL columnists. Journal of Modern Languages, 20, 64-79.

Vande Kopple, W. (1985). Some exploratory discourse on metadiscourse. College Composition and Communication, 36, 82-93.

van Dijk, T. (1988). News as Discourse. Hillsdale, New Jersey: Lawrence Erlbaum.

\section{Appendix}

Selected articles:

1. Demokrasi atau Borjuasi ('Democracy or Bourgeoisie'), September 21, 2013

2. Polisi Melawan Korupsi ('The Police Against Corruption'), September 20, 2013

3. Berharap kepada Komite HAM PBB ('Putting Hope in the UN Human Rights Commitee'), September 19, 2013

4. Kompetisi Asimetris ('Asymmetrical Competition'), September 18, 2013

5. Calon Presiden Pilihan Survei ('The Surveys' Candidate of President'), September 17, 2013

6. Sampah Visual Iklan Politik ('Political Advertisements' Visual Trash'), September 14, 2013

7. Demokrasi dan Politik Islam ('Democracy and Political Islam'): September 13, 2013

8. Demokratisasi Negara Hukum ('Legal State Democratization'), September 10, 2013

9. Republik Kartel ('The Republic of Cartel'), September 9, 2013

10. Lupakan Jokowi ('Forget about Jokowi'), September 9, 2013

11. Antara Jokowi dan "Surveyor" ('Between Jokowi and the "Surveyors"'), September 7, 2013 